\title{
PHYLOGENETIC RELATIONSHIPS OF AUSTRALIAN AND INDOCHINESE COTTON SPECIES
}

\author{
Sirojidinov B.A $\mathbf{1}^{\mathbf{1}}$. \\ ${ }^{1}$ Andijan State University \\ Rizaeva S.M ${ }^{2}$. \\ ${ }^{2}$ Institute of Genetics and Plant Experimental Biology,Uzbek Academy of Science, Tashkent, \\ Uzbekistan \\ Abdullaev A ${ }^{3}$. \\ ${ }^{2}$ Institute of Genetics and Plant Experimental Biology,Uzbek Academy of Science, Tashkent, \\ Uzbekistan
}

Article DOI: https://doi.org/10.36713/epra4041

\begin{abstract}
The article presents data on phylogenetic relationships of Australian and Indo-Chinese cotton species. A relatively close relationship of the wild species G.nelsonii with the subspecies G.arboreum is established. ssp. nanking when used as a maternal form during hybridization. It is noted that this wild species can be used as a valuable source material for breeding and genetic research in the creation of unique forms of cotton.
\end{abstract}

KEY WORDS: cotton, species, interspecific crossing, comparative morphology, hybridization.

\section{INTRODUCTION}

Today, the world pays special attention to the improvement and efficiency of genetic potential of economically valuable traits in cultivated plants through the use of their wild relatives. as well as the source material (Gossypium L.), genetically resistant to various stress factors, diseases and pests, which is one of the main branch of agriculture. One of the important goals in the modern world is the creation of productive varieties with competitive fiber, as well as the expansion of priorities for the further development of cotton growing.

Research on obtaining donors with economically valuable traits that are resistant to agricultural diseases and pests through the use of methods interspecific hybridization and experimental polyploidy within the genus Gossypium L. can see in the works of N.L.Innes (1992), Q.Liu \& al. (2015), S.S.Mehetre (1993), Yu.Chen \& al. (2014), L.Zhang \& al. (2010), J.M.Stewart (1995), M.A.Stanton \& al. (1992), Z.Y.Ma \& al. (1998), J.Luo \& al. (2012), B.T.Campbell \& al. (2010), H.Benbouza \& al. (2010), A.S.Ansingkar \& al. (2004). Also, in the CIS countries, G.S.Zaysev,
S.S.Kanash,
F.M.Mayer,
I.Kulibayeva
L.G.Arutunova,
A.Abdullayev,
I.Kulibayeva,
P.Valicek,
N.G.Simangulyan, S.M.Rizaeva, O.Kalonov, H.Babamuratov and many other scientists carried out the research obtained fruitful results on the evaluation of species of the genus Gossypium L., and creation on their basis of unique hybrid forms, resistant to biotic and abiotic environmental factors and enrichment of the gene pool of cotton in new genotypes.

In the course of research conducted in the Republic, Z.A.Ernazarova (1998) By hybridization of Australian cotton among species and their relatively degrees, caryo-structure of several wild species (Ahmedov, 1993) were studied by scientists. The phylogenetic relations of G.arboreum L. and it's species discriminations (Kuryazov, 2002; Muminov, Ernazarova, Rizayeva, 2008), morphometric and comparative policario-gramma of chromosomes in subspecies (Jumashev, 1996), separate forms subspecies of G.arboreum L. and anatomic structure of vegetative and generative organs of Australian cotton types were learned (Mamatyusupov, 2007). In this regard, research on the establishment of phylogenetic relationships 
between Australian and Indo-Chinese diploid cotton species, the search for opportunities for obtaining hybrids, the ascension to the level of hybrid forms hexaploid with new genotypes obtained on the basis of interspecific hybridization, the study of the inheritance and transgressive variability of morphological and economically valuable features of heterogeneous hexaploid $(2 \mathrm{n}=78)$ hybrids and the allocation of valuable sources of scientific and practical importance.

\section{MATERIAL AND METHODS}

In research classical methods of genetics and selection of cotton, interspecific hybridization, cytoembriology, comparative morphology, experimental polyploidy, modern methods of genetic and selection statistical analysis were used.

The object of the research were of Australian wild diploid species: G.sturtianum Willis var. sturtianum; G.sturtianum var. nandewarense (Der.) Fryx.; G.australe F.Muell.; G.nelsonii Fryx.; G.bickii Prokh.; intraspecific diversity of Indochinese species G.arboreum L.: ssp. obtusifolium (Roxb.) Mauer, ssp. obtusifolium var. indicum, ssp. perenne (Blanco) Mauer, ssp. neglectum (Tod) f. sanguineum, ssp. nanking (with brown fiber), ssp. nanking (with white fiber) from the world gene pool of cotton stored in the laboratory of Cotton systematics and introduction of the Institute of Genetics and experimental plant biology of AS RUz. Methods of interspecific hybridization were used in the research. Viability of pollen grains of $F_{1}$ hybrids was determined by cytological method (Z.Pausheva, 1988) - coloring with acetocarmine. The characteristic of morphobioligical signs $F_{1}$ and their parent forms is given on the basis of the method of comparative morphology and classification of genus Gossypium L. (N.Lemeshev, 1989). Statistical analysis of the obtained results was carried out using singlefactor and multi-factor analysis (ANOVA) and phylogenetic tree scheme in modern programs PAUP (FigTree v1.4.3).

\section{RESULTS}

The results of the analysis of the degree of knotting boxes and seeds in interspecific hybrids $\mathrm{F}_{0}$
Australian and Indo-Chinese species of cotton. There is a phenomenon of difficult crossing in the main part of the studied cotton species, indicating their distant relationship in phylogenetic relation. It should be noted that when using the for hybridization of G.arboreum subspecies nanking with white fiber as a maternal form, their relative proximity to the wild species of G.nelsonii is established.

Inheritance of quantitative traits in interspecific hybridization of diploid cotton species depends on mutual correspondence of chromosomes and genes with different genetic and evolutionary basis of species. Set high $(96,5-97,7 \%)$, the degree of the set full of seeds in one box in $\mathrm{F}_{1}$ hybrid combinations ssp. obtusifolium $\mathrm{x}$ var. nandewarense, ssp. nanking (with white fiber) $\mathrm{x}$ G.australe, ssp. nanking (with white fiber) x G.nelsonii, ssp. nanking (with white fiber) $\mathrm{x}$ G.bickii, ssp. obtusifolium var. indicum x G.australe, ssp. nanking (with brown fiber) x G.australe, derived from interspecific hybridization of Australian and IndoChinese cotton species. Installed comparison distant phylogenetic relationship in relation to G.australe as maternal forms with the subspecies ssp. obtusifolium, ssp. obtusifolium var. indicum, ssp. nanking (with white fiber) and low fertility of $F_{1}$ hybrids were observed. Hybrid $\mathrm{F}_{1}$ combinations ssp. obtusifolium x G.australe, ssp. obtusifolium x G.bickii, ssp. perenne x G.nelsonii, G.australe x ssp. neglectum f. sanguineum were sterile and they did not have the boxes tying marked. Sterility, in many cases, is not determined by a single mutation, but by the incompatibility of entire genotypes, which give an inappropriate combination leading, at least, to infertility. In other cases, sterility is determined by chromosome incompatibility due to large structural differences, namely translocations or more complex inversions (Schmalhausen, 1968).

No significant differences were found in the number of anthers in the flower and pollen grains in anthers in $\mathrm{F}_{1}$ hybrids G.australe x ssp. obtusifolium var. indicum, G.nelsonii x ssp. perenne. The wide variability of variability $(0,0-98,5 \%)$ in terms of fertility of pollen grains in $\mathrm{F}_{1}$ hybrids was noted (table. 1). 
Table 1

Cytoembryological indices of $F_{1}$ hybrids and their parent forms

\begin{tabular}{|c|c|c|c|}
\hline \multirow[b]{2}{*}{ Parent forms and hybrid combinations } & \multicolumn{3}{|c|}{ Cytoembryological indices } \\
\hline & $\begin{array}{l}\text { Number of } \\
\text { anthers, piece. }\end{array}$ & $\begin{array}{l}\text { Number of pollen } \\
\text { grains, piece. }\end{array}$ & $\begin{array}{c}\text { fertility of } \\
\text { pollen grains, } \\
\%\end{array}$ \\
\hline \multicolumn{4}{|c|}{ Parent forms } \\
\hline ssp. obtusifolium & $77,0 \pm 2,4$ & $235,7 \pm 5,6$ & $95,0 \pm 1,5$ \\
\hline ssp. obtusifolium var. indicum & $101,8 \pm 3,1$ & $273,7 \pm 6,1$ & $95,4 \pm 1,6$ \\
\hline ssp. perenne & $77,3 \pm 1,9$ & $271,4 \pm 7,1$ & $91,8 \pm 2,7$ \\
\hline ssp. neglectum f. sanguineum & $63,5 \pm 2,2$ & $233,2 \pm 11,3$ & $95,3 \pm 1,7$ \\
\hline ssp. nanking (with brown fiber) & $30,3 \pm 0,8$ & $212,4 \pm 13,5$ & $94,8 \pm 1,7$ \\
\hline ssp. nanking (with white fiber) & $33,8 \pm 0,8$ & $206,5 \pm 10,4$ & $93,7 \pm 1,8$ \\
\hline G.sturtianum var. sturtianum & $150,2 \pm 3,7$ & $260,3 \pm 4,0$ & $98,1 \pm 1,1$ \\
\hline G.sturtianum var. nandewarense & $177,6 \pm 4,3$ & $263,1 \pm 4,6$ & $98,6 \pm 1,0$ \\
\hline G.australe & $138,5 \pm 3,9$ & $228,9 \pm 6,3$ & $96,2 \pm 1,6$ \\
\hline G.nelsonii & $129,1 \pm 5,5$ & $230,4 \pm 5,7$ & $97,1 \pm 1,2$ \\
\hline G.bickii & $107,8 \pm 3,3$ & $214,1 \pm 5,6$ & $95,8 \pm 1,6$ \\
\hline \multicolumn{4}{|c|}{$F_{1}$ Hybrids } \\
\hline $\begin{array}{l}\text { ssp. obtusifolium x G.sturtianum var. } \\
\text { nandewarense }\end{array}$ & $69,8 \pm 0,8$ & $147,9 \pm 2,5$ & $94,2 \pm 1,8$ \\
\hline ssp. obtusifolium x G.australe & $17,4 \pm 0,9$ & $132,7 \pm 0,8$ & 0 \\
\hline G.australe x ssp. obtusifolium & $111,5 \pm 2,5$ & $154,4 \pm 1,1$ & $96,3 \pm 1,5$ \\
\hline ssp. obtusifolium x G.bickii & $50,1 \pm 1,1$ & $99,5 \pm 1,1$ & 0 \\
\hline $\begin{array}{l}\text { ssp. obtusifolium var. indicum x G.sturtianum var. } \\
\text { sturtianum }\end{array}$ & $54,6 \pm 2,3$ & $134,0 \pm 1,9$ & $88,7 \pm 1,5$ \\
\hline ssp. obtusifolium var. indicum x G.australe & $77,6 \pm 3,4$ & $123,5 \pm 0,7$ & $96,5 \pm 1,5$ \\
\hline G.australe x ssp. obtusifolium var. indicum & $77,8 \pm 1,4$ & $79,3 \pm 1,0$ & $72,7 \pm 1,5$ \\
\hline ssp. perenne x G.nelsonii & $45,1 \pm 1,6$ & $113,8 \pm 0,9$ & 0 \\
\hline G.nelsonii x ssp. perenne & $80,3 \pm 1,5$ & $85,5 \pm 1,0$ & $92,4 \pm 1,7$ \\
\hline $\begin{array}{l}\text { ssp. neglectum f. sanguineum x G.sturtianum var. } \\
\text { nandewarense }\end{array}$ & $20,7 \pm 1,2$ & $97,8 \pm 3,2$ & $77,1 \pm 2,0$ \\
\hline G.australe x ssp. neglectum f. sanguineum & $65,8 \pm 1,5$ & $188,8 \pm 1,1$ & 0 \\
\hline ssp. neglectum f. sanguineum x G.australe & $36,4 \pm 1,1$ & $123,0 \pm 0,7$ & $72,7 \pm 1,7$ \\
\hline $\begin{array}{l}\text { ssp. nanking (with brown fiber) x G.sturtianum } \\
\text { var. sturtianum }\end{array}$ & $28,1 \pm 1,2$ & $126,5 \pm 1,6$ & $94,4 \pm 1,9$ \\
\hline ssp. nanking (with brown fiber) x G.australe & $37,6 \pm 1,9$ & $154,1 \pm 1,0$ & $98,5 \pm 1,0$ \\
\hline G.australe x ssp. nanking (with brown fiber) & $15,9 \pm 0,6$ & $131,6 \pm 0,9$ & $93,4 \pm 2,1$ \\
\hline ssp. nanking (with brown fiber) x G.nelsonii & $36,7 \pm 3,3$ & $134,6 \pm 0,7$ & $97,7 \pm 1,3$ \\
\hline G.nelsonii x ssp. nanking (with brown fiber) & $72,5 \pm 1,7$ & $113,5 \pm 0,8$ & $93,8 \pm 1,6$ \\
\hline ssp. nanking (with white fiber) x G.australe & $22,1 \pm 1,1$ & $133,1 \pm 0,7$ & $96,1 \pm 1,6$ \\
\hline G.australe x ssp. nanking (with white fiber) & $78,3 \pm 1,8$ & $73,1 \pm 2,0$ & $67,5 \pm 1,4$ \\
\hline ssp. nanking (with white fiber) x G.nelsonii & $40,3 \pm 3,4$ & $164,6 \pm 0,9$ & $93,5 \pm 1,5$ \\
\hline ssp. nanking (with white fiber) x G.bickii & $39,8 \pm 1,2$ & $125,2 \pm 1,1$ & $97,4 \pm 1,3$ \\
\hline
\end{tabular}

The highest rate $(98,5 \%)$ on the basis of fertility of pollen grains was observed in the hybrid $\mathrm{F}_{1}$ ssp. nanking (with brown fiber) x $G$. australe. And in hybrid combinations $\mathrm{F}_{1}$ ssp. obtusifolium x $G$. australe, ssp. obtusifolium x $G$. bickii, ssp. perenne x $G$. nelsonii, $G$. australe $\mathrm{x}$ ssp. neglectum $\mathrm{f}$. sanguineum the fertility of pollen grains was $0,0 \%$, which indicates their sterility.
This in turn determines their distant phylogenetic relationship.

Based on the results of hybridological analyses and cytoembryological studied diploid species were divided into three groups by phylogenetic relationship (Fig. 1). 


\section{EPRA International Journal of Research and Development (IJRD)}

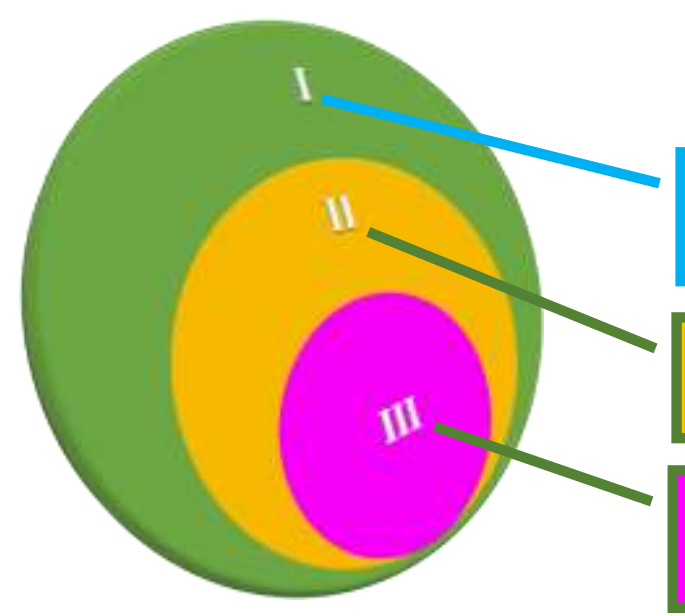

I-easily crossed (distant and close species) fertile $\mathrm{F}_{1}$ hybrids.

II-difficult to cross species with different genomes from different continents.

Figure 1. Group phylogenetic relationship of diploid Australian and Indochinese species of cotton

It should be noted that the research on the genetic potential of phylogenetically related groups of cotton species conducted By the laboratory of cotton systematics and introduction of the Institute of Genetics and experimental plant biology of the Academy of Sciences of the Republic of Uzbekistan has been confirmed.

The results of genetic analysis of F1 hybrids obtained on the basis of interspecific hybridization of heterogeneous cotton species indicate that in the manifestation of morphobiological features mainly intermediate inheritance is observed. In some cases, hybrids on morphobiological features were close to the signs of one of the parent forms, mainly the signs of the maternal form. This, in turn, indicates the cytoplasmic effect in the evolutionary process of the formation of hereditary traits in ecological and geographical distant cotton species. It should be noted that there were cases of non-compliance of parent forms in $F_{1}$ hybrids, including differences: 1) in the color and size of the flower, Guinea, the intensity of the anthocyanin stain (strong or weak); 2) the form, color, size, degree of pubescence of the leaf glands; 3 ) the height of the plant, the number of nodes to the first fruit branch, the degree of pubescence and anthocyanin The death of plants in the initial stage of the development period in hybrid combinations $\mathrm{F}_{1} G$. nelsonii x ssp. obtusifolium, var. sturtianum $\mathrm{x}$ ssp. obtusifolium var. indicum, ssp. obtusifolium var. indicum $\mathrm{x}$ var. nandewarense, ssp. obtusifolium var. indicum x $G$. nelsonii, obtusifolium var. indicum x $G$. bickii, $G$. bickii x ssp. obtusifolium var. indicum, ssp. perenne x $G$. bickii, $G$. bickii x ssp. perenne, var. sturtianum $\mathrm{x}$ ssp. neglectum $\mathrm{f}$. sanguineum, ssp. neglectum f. sanguineum $\mathrm{x} G$. nelsonii, ssp. neglectum f. sanguineum x G. bickii, var. nandewarense $\mathrm{x}$ ssp. nanking (with brown fiber), ssp. nanking (with brown fiber) x $G$. bickii, G. bickii x ssp. nanking (with brown fiber), var. nandewarense $\mathrm{x}$ ssp. nanking (with white fiber), $G$. nelsonii x ssp. nanking (with white fiber).

As a result of researches on the basis of the complex analysis of interspecific hybridization, cytoembriology, comparative morphology the new phylogenetic scheme of Australian and Indo-Chinese diploid cotton species is created, and also their systematic position is defined (Fig. 2). 


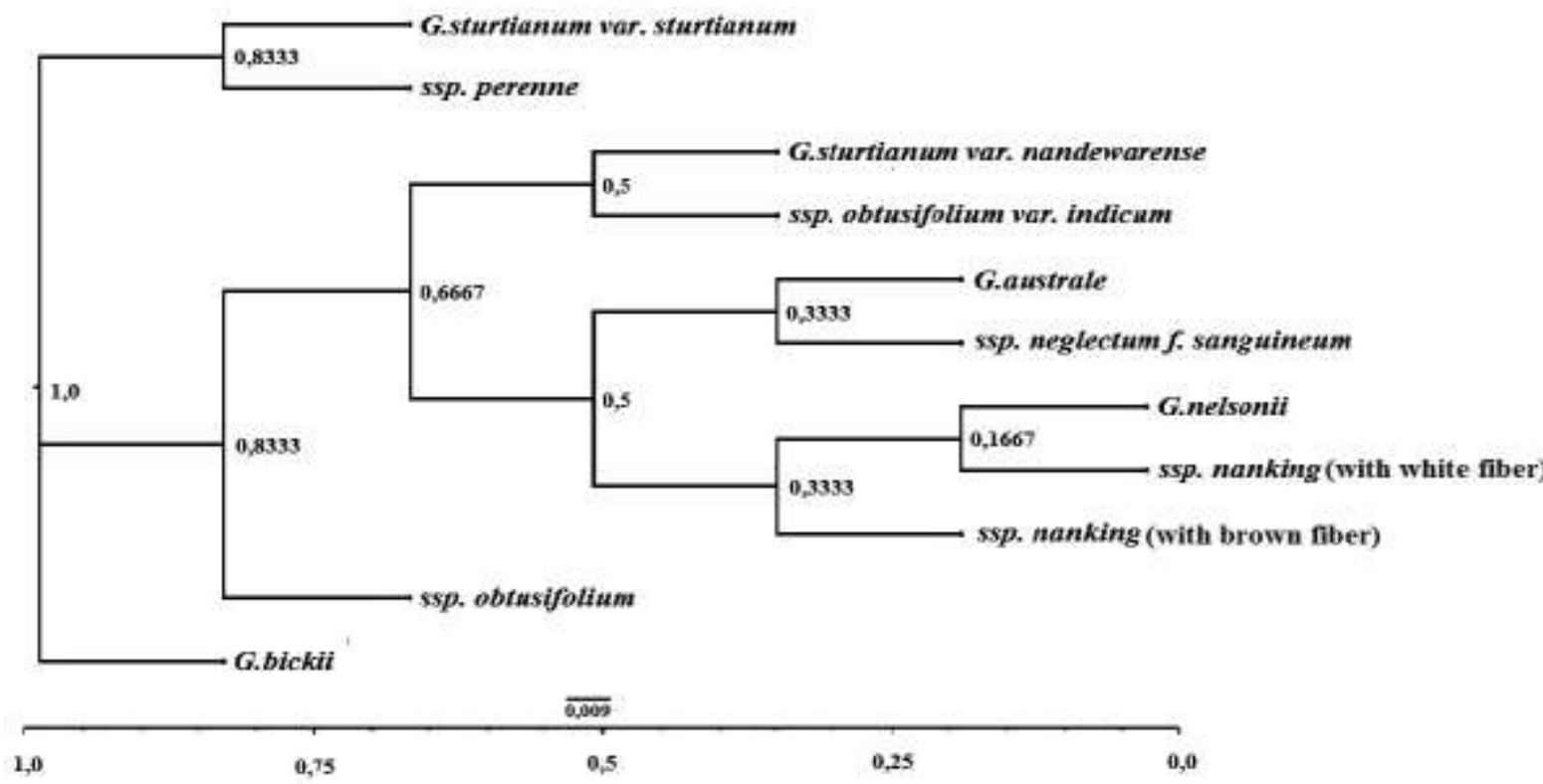

Figure 2. Phylogenetic scheme of Australian and Indo-Chinese cotton species

\section{DISCUSSIONS}

The scientific significance of the results of the study lies in the focus of research to establish phylogenetic relationships between Australian and Indo-Chinese diploid cotton species, a comprehensive analysis of the results of research, morphobiological and economic evaluation, the creation of a new phylogenetic scheme of cotton species and clarify their systematic position, the establishment of the possibility of ascension to the level of hybrid forms hexaloid with new genotypes, the disclosure of the nature of the inheritance and variability of signs in introgressive hybrid forms.

The practical significance of the results of the study lies in the fact that the use of unique introgressive hybrid recombinant, obtained on the basis of methods of interspecific and long-term hybridization and experimental polyploidy in genetic selection studies as a source material for solving practical problems and tasks of successful development of cotton Republic.

The practical results of the study are as follows:

the obtained results of the phylogenetic system of Australian and Indo-Chinese cotton species were used to improve the existing modern natural classification of intra-species systematics of polyploid species of the genus Gossypium L., to assess the biological characteristics and breeding potential of polyploid species, as well as the rational and effective use of the genetic potential of wild relatives of cultivated cotton species, to establish the nature of inheritance and variability of morphological economic and valuable features of introgressive hybrid forms;

The valuable hybrids allocated as a result of research are used in genetic selection programs as a source of useful signs on creation of new grades of unique polygenomic forms of cotton and improvement of economic signs at existing grades;

On the basis of methods of interspecific hybridization and experimental polyploidy unique introgressive hybrids are created, genetically enriched recombinant forms are selected and recommended for use in practical selection as a starting material.

\section{SUMMARY}

On the basis of the conducted researches on the theme "Phylogenetic relationships of Australian and Indo-Chinese cotton species" the following conclusions are presented:

1. A new phylogenetic scheme of Australian and Indo-Chinese diploid cotton species was created.

2. The relatively distant relationship in phylogenetic relation of Australian and Indo-Chinese diploid cotton species was established. When used in hybridization of G.arboreum subspecies nanking with white fiber as the parent form is established its relative close relationship with the wild species G.nelsonii. This, in turn, indicates the cytoplasmic effect of the evolutionary process in the formation of hereditary signs of ecological and geographically distant cotton species.

3. On the basis of analysis of interspecific hybridization, cytoembriology, comparative morphology and inheritance of morphobiological characteristics of diploid Australian and Indo-Chinese cotton species ssp. obtusifolium var. indicum species G.arboreum L. ascended to the rank of ssp. indicum self-subspecies. 
4. Obtained on the basis of intergenerational hybridization new synthetic complex hybrid forms, which have the potential of productivity in their carioplasm, as well as resistance to biotic and abiotic factors of the environment, will serve in genetic breeding programs as a valuable source material for the creation of new varieties of cotton of intensive type.

\section{REFERENCES}

1. Abdullayev A.A. Evolution and Systematics of polyploid species of cotton.- Tashkent: Fan, 1974.P. 260-262.

2. Ahmedov M.B. Karyology species of the genus Gossypium L. (systematic, phylogenetic and evolutionary aspects: Autoref. diss. ... Doc. Biol. Sci. - Tashkent: Botanical Institute of AS RUz.1993.- $30 \mathrm{p}$.

3. Ansingkar A.S., Khade P.P., Borikar S.T. and Bhosle S.S. Altering G. hirsutum cotton at cellular level to impart multiple sucking pest resistance through interspecific hybridization. // In: B.M.Khadi, I.S.Katageri, S.S.Patil, H.M. Vamadevaiah, B.R. Patil and S.M. Manjula (Eds), Proceedings of International symposium on "Strategies for Sustainable Cotton ProductionAGlobal Vision" 1, Crop Improvement, University of Agricultural Sciences, Dharwad, Karnataka (India), 2004. - P. 101-103.

4. Arutyunov, L. G. Interspecific hybridization in the genus Gossypium L. the genetics of breeding and seed production of cotton. Sat. art. - T., 1960. - P 3 71.

5. Babamuratov H. Inheritance of some morphological and economic features of three-genome hybrids of cotton / / in kN.: Genetics, breeding and seed production of cotton and alfalfa. - Tashkent, 1976. vol. 13. - P. 14-18.

6. Babamuratov H. Improving fiber quality and resistance of cotton through interspecific hybridization using backroom. "Tr. Research Institute of selection and seed growers. cotton", 1979, № 17, $7-12$.

7. Benbouza H, Lacape J.M, Jacquemin J.M, Courtois B, Diouf F.B.H, Sarr D, et al. Introgression of the lowgossypol seed \& high-gossypol plant trait in upland cotton: Analysis of [(Gossypium hirsutum $x$

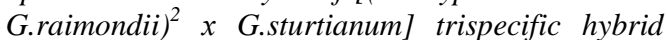
and selected derivatives using mapped SSRs. Mol Breeding. 2010.- Vol. 25.- P. 273-286.

8. Valichek P. Taxonomy and phylogenesis of cotton.: Diss....Doc. Biol.sciences'. - Tashkent: Institute of botany of the USSR. 1979. - 212 p.

9. Campbell B.T., Saha S., Percy R., Frelichowski J., Jenkins J., Park W., Mayee C.D., Gotmare V, Dessauw D, Giband M, Du X, Jia Y, Constable C., Dillon S., Abdurakhmonov I.Y., Abdukarimov A., Rizaeva S.M., Adullaev A, Barroso P.A.V., Padua J.G., Hoff Mann L.V., Podolnaya L. Status of the global Gossypium ssp. Germplasm resources // Crop Science, 2010. - Vol. 50. - P. 1161-1179.

10. Jumashev M.M. Caryosystematics intraspecific taxa old-cultivated cotton species.: Autoref. diss. ... Doc.
Biol. Sci.- Tashkent: Botanical Institute of AS RUz.1996.- 24 p.

11. Innes N.L. Gene banks and their contribution to the breeding of disease resistant cultivars. // Euphytica.- 1992.- 63. № 1-2, P. 23-31.

12. Kanash S.S. Interspecific hybridization within types of crossings with different chromosomes of cotton.Tashkent, Sages. 1932. - 56 p.

13. Kanash S.S. Interspecific hybridization within types of crossings with different chromosomes of cotton.In sat.: Summary and direction of the research work of the Central Union. - Tashkent, 1936. - P. 42-47.

14. Kolanov $O$. Analysis of intraspecific and interspecific hybrid combinations of diploid cultivated subspecies of cotton.: Autoref. Diss .... kand. Biol. sciences'. - Tashkent: Institute of botany of the USSR. 1986. -19-c 23.

15. Kulbaeva G. I. Polyploidy in the genus Gossypium L. and its cytological aspects. - Tashkent: Fan, 1975. - $104 \mathrm{p}$.

16. Liu $Q$, Chen $Y$, Chen $Y$, Wang $Y$, Chen J, Zhang $T$, et al. A New Synthetic Allotetraploid $\left(A_{1} A_{l} G_{2} G_{2}\right)$ between Gossypium herbaceum and G.australe: Bridging for Simultaneously Transferring Favorable Genes from These Two Diploid Species into Upland Cotton. PLoS ONE 2015.- 10 (4): P. 116.

17. Luo J., Cui J., Xin H. Relationship between the contents of cellulose and lignin in cotton leaf and their resistance to Apolygus lucorum. // Journal of Northwest $A$ \& $F$ University (Natural Science Edition).- 2012.- 40.- № 4, P. 81-85.

18. Ma Z.Y., Wang X.F., Zhang G.Y., Liu Z.G., Li X.H., Liu S.Q., et al. Distribution of the isolates of different virulence groups of Verticillium dahliae in Hebei cotton growing areas. // Journal of Agricultural University of Hebei.- 1998., 21.- №3, P. 1-6.

19. Mamatyusupov A.Sh. Comparative morphological and anatomical structure species of the genus Gossypium L.: Autoref. diss. ... Doc. Biol. Sci.Tashkent: SPC «Botany» AS RUz, 2007.- 19 p.

20. Mayer F.M. Origin and systematics of cotton.//Cotton.- Tashkent: AS Uz, 1954.- T. 1.- 384 p.

21. Mehetre S.S. Distant hybridization in cotton breeding-intergeneric hybridization (An overview). // J. Cotton Res \& Dev.- 1993. 7, № 2, P. 179-192.

22. Muminov H.A., Ernazarova Z.A., Rizayeva S.M. Combining ability of seeds at intraspecific hybridization varieties and forms and types of G.herbaceum L. and G.arboreum L.//Uzb. Bio. jour.- T., 2008.- Spec. Pub.- P. 21-23.

23. Rizaeva $S$. M. The use of intergenomic hybrids section Integrifolia Tod. for bogdania AD1, position W2 - genome of cotton.: Autoref. dis. ... kand. biologist. sciences'. - Tashkent. 1983. - 21 p.

24. Rizaeva S. M. Distant hybridization of cotton and obtaining new donors (on the example of new secular species): author. dis.... dock. Biol. sciences'.- Tashkent. 1996.- 50 p.

25. Simongulyan N.G. Genetics, selection and seed production of cotton. - Tashkent: Tanshkent, 1980. 
- P. 65-67.

26. Simongulyan N.G. Genetics of quantitative traits of cotton. - Tashkent: FAN, 1991. - 123 p.

27. Stewart, J.M. Potential for crop improvement with exotic germplasm and genetic engineering. // In: Constable GA, Forrester NW (eds) Challenging the future: Proceedings of the World Cotton research Conference-1, Brisbane Australia. 1995.- P. 313327.

28. Stanton M.A., Stewart J.Mc.D., Tugwell N.P. Evaluation of Gossypium arboreum L. Germplasm for resistance to thrips. // Gent. Res. and Crop Evol.- 1992.- 39. - № 2, P. 89-95.

29. Yu Chen, Yingying Wang, Kai Wang, Xiefei Zhu, Wangzhen Guo, Tianzhen Zhang, Baoliang Zhou. Construction of a complete set of alien chromosome addition lines from Gossypium australe in Gossypium hirsutum: morphological, cytological, and genotypic characterization. // Theor Appl Genet. 2014.- Vol. 127, P. 1105-1121.

30. Ernazarova Z.A. Interspecies relationship with the cotton-genomic and phylogenetic relationships with D-genomic species: Autoref. diss. ... Doc. Biol. Sci.Tashkent: IGPEB AS RUz.- 1998.- 153 p.

31. Zaysev G.S. The classification of the genus Gossypium L. // Bulletin of applied botany, genetics and breeding, 1927-1928.- T. 18. - №.12.- P. 1-38.

32. Zhang L., Li F., Liu C., Zhang C., Wu Z. Isolation and analysis of drought -related genefrom cotton (Gossypium arboreum L.) SSH library. // Cotton Science. 2010.- Vol. 22, P. 110-114. 